Abstracta Iranica Abstanica

Revue bibliographique pour le domaine irano-aryen

Volume 34-35-36 | 2017

Comptes rendus des publications de 2011-2013

\title{
Michele Minardi. A four-armed goddess from Ancient Chorasmia: history, iconography and style of an Ancient Chorasmian icon
}

Johanna Lhuillier

\section{(2) OpenEdition \\ Journals}

Édition électronique

URL : http://journals.openedition.org/abstractairanica/42040

DOI : $10.4000 /$ abstractairanica.42040

ISSN : 1961-960X

Éditeur :

CNRS (UMR 7528 Mondes iraniens et indiens), Éditions de l'IFRI

Référence électronique

Johanna Lhuillier, « Michele Minardi. A four-armed goddess from Ancient Chorasmia: history, iconography and style of an Ancient Chorasmian icon », Abstracta Iranica [En ligne], Volume 34-35-36 | 2017,

document 5, mis en ligne le 30 juillet 2017, consulté le 03 octobre 2020. URL : http://

journals.openedition.org/abstractairanica/42040; DOI : https://doi.org/10.4000/abstractairanica. 42040

Ce document a été généré automatiquement le 3 octobre 2020.

Tous droits réservés 


\section{Michele Minardi. A four-armed goddess from Ancient Chorasmia: history, iconography and style of an Ancient Chorasmian icon}

Johanna Lhuillier

\section{RÉFÉRENCE}

Michele Minardi. «A four-armed goddess from Ancient Chorasmia: history, iconography and style of an Ancient Chorasmian icon ». Iran 51, 2013, p. 111-143.

1 L'A. livre une nouvelle étude d'un emblema représentant une divinité féminine à quatre bras figurant sur un vase en argent découvert en Chorasmie (Ouzbékistan) et publié pour la première fois en 1909, croisant approches iconographique, stylistique et historique. Cette divinité, qui apparaît sur d'autres vases, était sans doute vénérée en Chorasmie antique.

Cette représentation doit se comprendre dans un contexte d'échanges d'hommes, de biens et d'idées qui relient la Chorasmie à la Sogdiane, l'Empire romain d'Orient, la Chine et le Khaganat turc occidental, et elle est l'héritière de modèles iconographiques perses sassanides, kouchans, et hellénistiques/romains.

3 L'A. suggère que l'association d'un style qu'il identifie comme celui de l'Empire byzantin et d'une iconographie proche de celle des déesses indiennes pourrait refléter le rôle intermédiaire joué par la Chorasmie entre ces deux régions. En s'appuyant sur l'inscription en chorasmo-araméen qui figure sur le bol, sur les données historiques, archéologiques et sur des parallèles iconographiques et stylistiques, il propose une nouvelle datation du bol dans la seconde moitié du VI ${ }^{\mathrm{e}} \mathrm{s}$. ou le début du VII siècle. 


\section{AUTEURS}

\section{JOHANNA LHUILLIER}

UMR 5133 CNRS-Université de Lyon 